\title{
HUBUNGAN ANTARA STATUS GIZI IBU HAMIL DENGAN BERAT BADAN BAYI LAHIR
}

\author{
Maretha Herwati ${ }^{1}$, Dewi Andang Prastika ${ }^{2}$, Listyaning Eko Martanti² \\ ${ }^{1}$ Puskesmas Tunjungan Dinkes Kabupaten Blora \\ 2Poltekkes Kemenkes Semarang \\ email : maretha006@gmail.com
}

Riwayat Artikel: Diterima: 27 Oktober 2021, direvisi: 25 November 2021, dipublikasi: 29 November 2021

\begin{abstract}
Nutritional status is one of the determining factors that influence the success of health development. Nutritional problems that often happened in pregnancy are chronic lack of energy (KEK) and anemia. Both of them can inhibit fetal growth thus posing a risk of BBLR. BBLR is a birth weigh below 2500 grams. This study aimed to determine and analysed the relationship between the nutritional status of pregnant women and the weight of babies born in the Tunjungan Health Center, Blora Regency. The design of this study is Observational Analytics with a retrospective approach using secondary data of medical records, especially the maternity data of UPTD Tunjungan Helath Center, Blora Regency. The population in this study was 549 and was taken as a sample of 231 using systematic random sampling. The results of this study showed that there was a significant relation between the nutritional status of pregnant women and the weight of the baby born which was proven from the test value of chi-quare with $p 0.000$. The most of respondents in this study are pregnant women whose KEK is $59.3 \%$ and gave birth to BBLR babies (72\%) Based on the results of this study, it is highly recommended for pregnant women to meet optimal nutritional needs to prevent the birth of $B B L R$.
\end{abstract}

Keywords : Nutritional Status; Pregnant Women; Weight; New-born

\begin{abstract}
ABSTRAK
Status gizi yang baik adalah salah satu faktor penentu keberhasilan pembangunan kesehatan. Masalah gizi yang sering dihadapi ibu hamil yaitu Kurang Energi Kronik (KEK) dan anemia gizi dapat menghambat pertumbuhan janin sehingga menimbulkan risiko BBLR. BBLR merupakan berat badan lahir di bawah 2500 gram. Penelitian ini bertujuan untuk mempelajari dan menganalisis hubungan antara status gizi ibu hamil dengan berat badan bayi lahir di Puskesmas Tunjungan Kabupaten Blora. Desain atau rancangan penelitian ini bersifat Analitik Observasional dengan pendekatan retrospektif menggunakan data sekunder rekam medik khususnya data persalinan UPTD Puskesmas Tunjungan Kabupaten Blora. Populasi dalam penelitian ini sejumlah 549 dan diambil sebagai sampel sejumlah 231 menggunakan random sampling sistematis. Hasil penelitian ini menunjukkan bahwa ada hubungan yang signifikan antara status gizi ibu hamil dengan berat badan bayi lahir yang terbukti dari nilai uji chi-quare $\mathrm{p} 0,000$. Ibu hamil dengan KEK, 72\% nya melahirkan bayi BBLR. Berdasarkan hasil penelitian ini, sangat direkomendasikan bagi ibu hamil untuk memenuhi kebutuhan gizi yang optimal untuk mencegah kelahiran BBLR.
\end{abstract}

Kata kunci : Status Gizi; Ibu Hamil; Berat Badan; Bayi Lahir

\section{Pendahuluan}

Gizi adalah salah satu aspek yang penting dalam kehidupan manusia. Upaya perbaikan status gizi berkontribusi dalam mencapai tujuan pembangunan nasional, 
terutama pada penurunan prevalensi gizi kurang pada balita, anak SD atau MI dan ibu hamil dengan Kurang Energi Kronik (KEK). Salah satu faktor yang dijadikan sebagai indikator keberhasilan pembangunan kesehatan adalah status gizi yang baik, sehingga hal tersebut tidak dapat dipisahkan dari pembangunan nasional (KEMENKES RI 2015).

Data status gizi ibu hamil dan berat lahir bayi di wilayah kerja Puskesmas Tunjungan Pada tahun 2019, diketahui dari 673 ibu hamil yang ada 128 diantaranya menderita KEK (19,02\%). Persalinan tahun 2019 berjumlah 660, 123 bayi lahir dengan berat bayi lahir rendah (23\%) (Puskesmas Tunjungan 2019). Tahun 2020, dari 695 ibu hamil ada 172 ibu hamil yang menderita KEK (25\%). Data tahun 2020 menunjukkan jumlah persalinan adalah 674 kelahiran terdapat 164 bayi lahir dengan berat bayi lahir rendah (24\%). Data ini menunjukkan bahwa status gizi ibu hamil yang kurang mengalami peningkatan (Puskesmas Tunjungan 2020). Dari tingginya ibu hamil dengan status gizi kurang kemungkinan besar melahirkan bayi BBLR.

Ibu hamil dengan KEK adalah salah satu penyebab terjadinya Bayi dengan BBLR. Beberapa dampak BBLR adalah pertumbuhan fisik dan perkembangan mental yang melambat, serta penurunan kecerdasan (IQ). Ada beberapa faktor yang diperkirakan berhubungan dengan faktor risiko BBLR dan kelahiran prematur (Mayanda 2017). Salah satunya adalah malnutrisi atau kurang gizi pada ibu hamil. Oleh karena itu, ibu hamil dianjurkan untuk melakukan diet seimbang dan mendapatkan suplementasi vitamin yang mengandung seng $(\mathrm{Zn})$ selama masa hamil. Beberapa penelitian terakhir mengaitkan BBLR dan kelahiran premature dengan defisiensi seng (Puspitaningrum 2018).

Upaya-upaya yang dilakukan pemerintah dalam menangani permasalahan gizi pada ibu hamil meliputi program-program yang dilaksanakan olah Pemerintah diantaranya kelas lbu hamil yang dilakasanakan dalam rangka memberikan pengetahuan akan pentingnya gizi pada ibu saat hamil, program pemberian makanan tambahan bagi ibu hamil KEK berupa biskuit dan susu. Pemberian suplementasi gizi tersebut adalah salah suatu upaya yang dapat dilakukan untuk mencukupi kekurangan kebutuhan gizi dari konsumsi makan harian yang dapat mengakibatkan timbulnya masalah kesehatan dan gizi (KEMENKES RI 2018).

Tujuan penelitian ini adalah untuk menganalisis hubungan antara status gizi ibu hamil dengan berat badan bayi lahir di Puskesmas Tunjungan Kabupaten Blora. Perbedaan penelitian ini dengan penelitian sebelumnya oleh (Susanti 2018) maupun (Anggrenisa 2018) yang telah melakukan penelitian serupa, dimana perbedaan tersebut terletak pada desain penelitian yang digunakan.

\section{Metode Penelitian}

Desain penelitian yang digunakan adalah Analitik Observasional melalui survey cross sectional dengan pendekatan retrospektif. Data yang digunakan adalah data sekunder rekam medik khususnya data persalinan UPTD Puskesmas Tunjungan Kabupaten Blora, periode Januari - Desember 2020.

Populasi penelitian ini adalah ibu hamil yang melakukan pemeriksaan kehamilan dan melahirkan di Puskesmas Tunjungan periode 1 Januari 2020 - 31 Desember 2020, sejumlah 549 responden. Sampel dihitung menggunakan rumus solvin, dengan hasil perhitungan sejumlah 231 responden. Teknik pengambilan sampel dengan menggunakan menggunakan random sampling sistematis. Kriterian inklusi penelitian adalah Ibu hamil yang melahirkan dengan usia kehamilan 37 minggu sampai dengan 42 minggu dan bersalin dengan persalinan normal (kala I sampai kala IV di Puskesmas Tunjungan), sedangkan kriteria eksklusi adalah lbu hamil usia kehamilan 37 minggu sampai 42 minggu yang melahirkan di Puskesmas Tunjungan dengan catatan RM tidak lengkap.

Instrumen penelitian yang digunakan adalah formulir data penelitian yang bersumber dari data Rekam Medis persalinan yang terdiri dari Kode Responden, Berat Badan Bayi Lahir, Usia Ibu Hamil, Status Gizi lbu Hamil, Paritas, Jarak Kehamilan, Pendidikan, Pekerjaa. Data hasil penelitian dianalisis dengan uji chi-square menggunakan perangkat SPSS. 


\section{Hasil Dan Pembahasan}

Penelitian tentang status gizi ibu hamil telah dilaksanakan. Data dan hasil analisis disajikan dalam artikel ini.

Tabel 1. Distribusi Frekuensi Karakteristik Responden

\begin{tabular}{|c|c|c|}
\hline Karakterisitk & $\mathrm{f}$ & $\%$ \\
\hline \multicolumn{3}{|l|}{ Usia } \\
\hline Risiko tinggi & 146 & 63,2 \\
\hline Tidak Risiko Tinggi & 85 & 36,8 \\
\hline Total & 231 & 100 \\
\hline \multicolumn{3}{|l|}{ Pendidikan } \\
\hline Dasar & 159 & 68,8 \\
\hline Menengah & 72 & 31,2 \\
\hline Total & 231 & 100 \\
\hline \multicolumn{3}{|l|}{ Pekerjaan } \\
\hline IRT & 108 & 46,8 \\
\hline Buruh Tani & 67 & 29 \\
\hline Wiraswasta & 39 & 16,9 \\
\hline ASN & 17 & 7,4 \\
\hline Total & 231 & 100 \\
\hline \multicolumn{3}{|l|}{ Paritas } \\
\hline Primipara & 60 & 26 \\
\hline Multipara & 58 & 25,1 \\
\hline Grande & 113 & 48,9 \\
\hline Multipara & & \\
\hline Total & 231 & 100 \\
\hline \multicolumn{3}{|l|}{ Jarak kelahiran } \\
\hline Resiko tinggi & 67 & 29 \\
\hline Tidak Resiko tinggi & 164 & 71 \\
\hline Total & 231 & 100 \\
\hline \multicolumn{3}{|l|}{ Status Gizi Bumil } \\
\hline KEK & 137 & 59,3 \\
\hline Normal & 94 & 40,7 \\
\hline Total & 231 & 100 \\
\hline \multicolumn{3}{|l|}{ BB Bayi Lahir } \\
\hline BBLR & 122 & 52,8 \\
\hline BBLN & 57 & 24,7 \\
\hline BBLB & 52 & 22,5 \\
\hline Total & 231 & 100 \\
\hline
\end{tabular}

$\mathrm{f}=$ Frekuensi, $\%=$ Prosentase, IRT = Ibu Rumah Tangga, ASN $=$ Aparatur Sipil Negara, $\mathrm{KEK}=$ Kurang Energi Kronik $\mathrm{BB}=$ Berat Badan, BBLR = Berat Badan Lahir Rendah, BBLN $=$ Berat Badan Lahir Normal, BBLB = Berat Badan Lahir Berlebih

Penelitian ini menunjukkan bahwa sebagian besar ibu hamil di wilayah kerja UPTD Puskesmas Tunjungan memiliki usia risiko tinggi yaitu sejumlah 146 atau $63,2 \%$ (tabel 1). Yang dimaksud dengan usia resiko tinggi adalah ibu hamil berusia $<20$ tahun atau > 35 tahun. Hasil penelitian ini sesuai dengan studi yang menjelaskan bahwa usia ibu saat melahirkan kurang dari 18 dan lebih dari 35 tahun berhubungan dengan peningkatan risiko BBLR. Studi epidemiologi pada jumlah yang besar melaporkan bahwa BBLR terjadi pada ibu dengan usia muda dan tua (Momeni et al. 2017).

Tingkat Pendidikan responden yang mendominasi pada penelitian ini adalah pendidikan dasar (SD atau MI dan SMP atau MTS) yaitu sejumlah 159 orang atau $68,8 \%$ (tabel 1). Pendidikan ibu akan berpengaruh terhadap bagaimana orang bersikap dan bertindak dalam menghadapi masalah termasukupaya mencegah kejadian BBLR melalui pengaturan makanan bagi ibu hamil (Windari 2015).

Pekerjaan ibu hamil sebagian besar pada penelitian ini adalah IRT, sejumlah 108 orang atau 46,8\% (tabel 1). Sebuah studi melaporkan bahwa jenis pekerjaan dan waktu istirahat merupakan salah satu variable penting yang berhubungan dengan kejadian BBLR. Pekerjaan wanita dibagi menjadi tiga kateogir dasar yaitu, ibu rumah tangga, bekerja sebagai pembantu rumah tangga dan bekerja sebagai buruh di beberapa tempat kerja. Dua kategori pekerjaan terakhir, selain mengerjakan pekerjaan di tempat kerja, juga harus mengurus pekerjaan rumah tangga mereka sendiri. Mayoritas ibu yang melahirkan bayi BBLR bekerja sebagai buruh, yaitu sebesar $71,4 \%$, hal tersebut menunjukkan perbedaan yang signifikan antara ketiga jenis pekerjaan. Durasi istirahat siang juga berkaitan dengan kejadian BBLR, dimana $76,5 \%$ ibu hamil yang tidur siang kurang dari 1 jam setiap harinya, melahirkan bayi BBLR (Choudhary et al. 2013).

Paritas sebagian besar ibu pada penelitian ini adalah grande multipara (kehamilan lebih dari 5 kali melahirkan bayi baik yang hidup maupun mati) yaitu sejumlah 113 orang atau 48,9\% (tabel 1 ). Penelitian sebelumnya menjelaskan bahwa ibu dengan paritas tinggi berisiko melahirkan bayi yang BBLR 0,2 kali dibandingkan ibu dengan paritas rendah (Mayanda 2017). Paritas yang terlalu tinggi akan menyebabkan gangguan pada uterus terutama pada pembuluh darah, sehingga dapat menyebabkan kerusakan pada dinding pembuluh darah uterus yang dapat mengakibatkan atonia uteri (Susanti 2018). 
Ibu hamil yang sudah pernah melahirkan 4 kali lebih berpotensi mengalami gangguan kesehatan, kurang gizi dan anemia (Jumhati and Novianti 2018).

Pada penelitian ini menunjukkan bahwa sebanyak 67 orang atau $29 \%$ memiliki jarak kelahiran risiko tinggi, yaitu kurang dari 2 tahun (tabel 1). Sebuah studi melaporkan bahwa jarak kehamilan berpengaruh terhadap kejadian BBLR, dimana ibu hamil dengan jarak kehamilan < 2 tahun 3,199 kali lebih berisiko melahirkan bayi dengan BBLR (Nasution 2018), bahkan studi lain melaporkan risiko terjadinya BBLR pada jarak kehamilan $<2$ tahun adalah sebesar 14,7 kali lebih besar (Jumhati and Novianti 2018).

Hasil penelitian ini juga mendeskripsikan status gizi ibu hamil di UPTD Puskesmas Tunjungan yang menunjukkan sebagian besar ibu mengalami status gizi KEK (Kurang Energi Kronik, dengan LILA $<23,5 \mathrm{~cm}$ ) yaitu sebanyak 137 orang atau 59,3\% (tabel 1) dan sebagian besar diantarany yaitu 99 ibu atau $72 \%$ (tabel 2) melahirkan bayi dengan berat badan lahir rendah. Penelitian sebelumnya melaporkan bahwa ibu yang memiliki LILA tidak normal berisiko 8 kali lebih besar untuk melahirkan bayi BBLR dibandingkan dengan ibu LILA normal (Mayanda 2017). Ibu hamil dengan KEK dapat berdampak buruk pada pertumbuhan janin. Komplikasi yang dapat terjadi diantaranya abortus, BBLR, kematian neonatal, bayi lahir mati dan anemia pada bayi (Kusuma, Astuti, and Kusumawardhani 2019).

Hasil analisis perhitungan uji Chi-Square antara variabel status gizi ibu hami dengan variabel berat badan bayi lahir diperoleh nilai $p=0,000$ atau kurang dari 0,05 (tabel 2), artinya ada hubungan signifikan antara status gizi ibu hamil dengan berat badan bayi lahir di UPTD Puskesmas Tunjungan Kabupaten Blora Tahun 2020. Sebagian besar ibu hamil di Puskesmas Tunjungan mengalami status gizi KEK yaitu sejumlah 137 orang (59,3\%), sedangkan 94 $(40,7 \%)$ lainnya berstatus gizi normal (tabel 1).

Ibu hamil dengan KEK mendominasi kelahiran bayi dengan BBLR (Berat badan lahir < 2500 gram) yaitu 99 (72\%) orang, sedangkan yang lainnya yaitu 27 (20\%) melahirkan bayi BBL Normal dan sebagian kecil yaitu $11(8 \%)$ orang melahirkan bayi BBL Lebih (tabel 2). Bayi BBLR di Puskesmas Tunjungan tidak hanya terlahir dari ibu dengan status gizi KEK, namun juga terlahir dari ibu dengan status gizi normal. Dari penelitian ini diketahui bahwa dari 94 ibu hamil berstatus gizi normal, 23 (24\%) orang melahirkan bayi BBLR, 30 (32\%) orang melahirkan bayi BBL normal, dan 41 (44\%) orang melahirkan bayi BBL berlebih. Angka tersebut menunjukkan bahwa status gizi ibu hamil memiliki hubungan dengan bayi BBLR yang terbukti dengan angka kejadian bayi BBLR lebih banyak dijumpai pada ibu hamil yang kekurangan energi kronis dari pada ibu berstatus gizi normal. Penelitian ini juga menggambarkan bahwa kejadian BBLR tidak hanya terlahir dari ibu hamil yang kekurangan energi kronis, namun dijumpai pula angka kelahiran BBLR sebesar $24 \%$ dari ibu berstatus gizi normal. Walaupun ada sebagian ibu dengan status gizi normal melahirkan bayi dengan BBLR, namun mayoritas melahirkan bayi dengan berat berlebih.

Sebuah studi melaporkan bahwa $91,7 \%$ bayi dengan BBLR, lahir dari ibu yang mengkonsumsi kalori antara 1800 sampai 2000 kalori per hari. Proporsi tersebut semakin menurun seiring dengan peningkatan konsumsi kalori, dimana pada ibu yang mengkonsumsi kalori harian 2400 kalori, hanya $6,3 \%$ diantaranya melahirkan bayi dengan BBLR (Choudhary et al. 2013).

Pada ibu dengan status gizi normal, kelahiran bayi BBLR dapat dipengaruhi oleh berbagai faktor. Studi terhadap penyebab terjadinya BBLR masih terus dilaksanakan. Beberapa studi melaporkan bahwa BBLR disebabkan oleh multifaktor baik faktor ibu, faktor janin maupun faktor lingkungan. Faktor ibu meliputi demografi seperti pendidikan, pekerjaan dan ras; perilaku seperti merokok atau minum alkohol; biomedis seperti umur, paritas, berat badan, jarak kehamilan, riwayat obstetri, tekanan darah, dan kadar haemoglobin ibu selama hamil. Faktor janin meliputi anomali kromosom, hidramnion dan kehamilan kembar. Sedangkan faktor lingkungan yaitu paparan polusi udara (Ani, Umaroh, and Hardjanti 2020). 
Tabel 2. Hasil Analisis Hubungan Antara Status Gizi lbu Hamil dengan BBLR

\begin{tabular}{lccccccccc}
\hline \multirow{2}{*}{$\begin{array}{c}\text { Status Gizi } \\
\text { Bumil }\end{array}$} & \multicolumn{8}{c}{ Rerat Badan Bayi Lahir } & \multirow{2}{*}{ p-value } \\
\cline { 2 - 10 } \multicolumn{1}{c}{} & $\mathrm{N}$ & $\%$ & $\mathrm{n}$ & $\%$ & $\mathrm{n}$ & $\%$ & $\mathrm{n}$ & $\%$ & \\
\hline KEK & 99 & 72 & 27 & 20 & 11 & 8 & 137 & 100 & \multirow{2}{*}{0,000} \\
Normal & 23 & 24 & 30 & 32 & 41 & 44 & 94 & 100 & 0 \\
\hline
\end{tabular}

Organ reproduksi pada ibu usia kurang dari 20 tahun belum berkembang sempurna, menyebabkan suplai aliran darah ke serviks dan uterus berkurang, sehingga meningkatkan risiko kejadian BBLR. Suplai darah ke rahim yang kurang mengakibatkan janin kekurangan nutrisi untuk tumbuh dan berkembang sehingga bayi lahir memiliki berat badan kurang dari normal (Sujianti 2018). Pada ibu hamil yang dengan usai lebih muda, kemungkinan ada beberapa permasalahan sosial seperti status sosial ekonomi rendah, pendidikan rendah, gizi buruk, serta IMT rendah (Momeni et al. 2017)

Kehamilan di usia tua juga merupakan kehamilan berisiko karena semakin tua usia ibu akan semakin besar kemungkinan terjadinya komplikasi seperti hipertensi, aterosklerosis, diabetes (Kurniawan and Sjahriani 2014) dan kelainan kromosom. Banyak studi epidemiologi dan biologi yang mendukung fakta bahwa faktor risiko medis ibu seperti diabetes melitus gestasional dan hipertensi dalam kehamilan, secara signifikan berhubungan dengan BBLR. Diabetes melitus gestasional dapat menyebabkan persalinan prematur dan komplikasi lain juga. Selain itu, pengobatan konvensional pada diabetes melitus gestasional dapat meningkatkan risiko BBLR (Momeni et al. 2017).

Usia > 40 tahun adalah salah satu faktor risiko preeklampsia, sebagai bagian dari hipertensi dalam kehamilan. Hal tersebut disebabkan karena semakin bertambah usia seseorang akan terjadi perubahan endotel pada pembuluh darah (Yuliani, Hadisaputro, and Nugraheni 2019). Salah satu tanda preeklampsia adalah gangguan pertumbuhan janin. Hal tersebut terjadi akibat adanya gangguan pada sirkulasi uteroplasenta (Wibowo et al. 2016) atau menurunnya sirkulasi darah antara utero-plasenta yang meningkatkan risiko BBLR (Momeni et al. 2017). Bahkan dapat menyebabkan bayi lahir dengan berat lahir rendah, walaupun usia kehamilan cukup bulan.

Pendidikan adalah salah satu faktor yang dapat mempengaruhi kejadian BBLR. (Kurniawan and Sjahriani 2014). Sebuah studi melaporkan bahwa tingkat Pendidikan ibu yang lebih rendah menyertai peningkatan risiko kejadian BBLR. Dimana ibu yang buta huruf berisiko 1,91 kali, ibu dengan pendidikan dasar berisiko 1,60 kali, ibu dengan pendidikan sekolah menengah berisiko 1,41 kali dan ibu dengan Pendidikan sekolah menengah atas berisiko 1,22 kali untuk kejadian BBLR. Hasil yang menghubungkan antara pendidikan dengan kejadian BBLR tersebut sesuai dengan hasil studi lain baik secara nasional maupun internasional. Tingkat Pendidikan dikaitkan dengan meningkatnya informasi tentang kesehatan pada ibu dengan Pendidikan lebih tinggi (Momeni et al. 2017). Informasi kesehatan yang dimaksud misalnya kebutuhan nutrisi pada saat hamil, usia reproduksi sehat, dan informasi seputar kehamilan (Kurniawan and Sjahriani 2014).

Sebuah studi melaporkan bahwa tingkat pendidikan ibu secara signifikan berkorelasi erat dengan terjadinya BBLR. Semakin rendah tingkat pendidikan ibu maka semakin tinggi kejadian BBLR. Di China, sesuai dengan perkembangan sosial budaya yang berkelanjutan dan pemberlakuan wajib belajar, maka sebagian besar wanita hamil dengan tingkat pendidikan rendah tinggal di daerah terpencil yang secara ekonomi tertinggal. Oleh karena itu mereka cenderung kurang informasi tentang perawatan kesehatan kehamilan termasuk informasi tentang gizi. Selain itu tingkat pelayanan kesehatan lokal juga cenderung kurang baik, mencegah ibu hamil untuk 
menjalani pemeriksaan rutin selama kehamilan, sehingga meningkatkan kejadian BBLR (Chen et al. 2013).

Menurut DEPKES RI, jarak kehamilan ideal yang direkomendasikan adalah lebih dari atau sama dengan 2 tahun atau 24 bulan, karena kondisi tubuh terutama rahim ibu butuh waktu untuk pulih secara keseluruhan. Jika kehamilan terjadi kurang dari 2 tahun akan berisiko terjadi gangguan pertumbuhan janin, persalinan lama serta perdarahan intrapartum (Nasution 2018) dan (Jumhati and Novianti 2018). Jarak antar kehamilan yang terlalu dekat menyebabkan cadangan $\mathrm{Fe}$ yang terbentuk masih sangat sedikit. Jika kehamilan terjadi pada saat persediaan cadangan $\mathrm{Fe}$ minimal, maka akan menguras persediaan Fe pada tubuh, sehingga dapat menyebabkan anemia pada kehamilan berikutnya dan berisiko melahirkan bayi dengan BBLR (Kurniawan and Sjahriani 2014).

Kelahiran BBLR dapat dikendalikan dengan upaya promotif, preventif, kuratif dan rehabilitatif secara terpadu. Pencegahan dalam aspek promotif dapat dilakukan dengan memberikan pendidikan kesehatan (memberikan informasi) kepada ibu hamil tentang upaya kesehatan di masa kehamilan, salah satunya informasi tentang kebutuhan gizi ibu selama masa kehamilan. Adapun beberapa informasi kebutuhan nutrisi bagi ibu hamil yang dapat disampaikan kepada ibu agar janin yang di kandung dapat lahir dengan sehat dan cerdas meliputi kebutuhan energi, protein, kalsium, asam folat, zat besi, vitamin, zing dan lain-lain (Yuliani et al. 2021).

\section{Kesimpulan}

Hasil penelitian menunjukkan bahwa sebagian besar ibu adalah usia risiko tinggi, berpendidikan tingkat dasar, bekerja sebagai ibu rumah tangga, paritas grande multipara dan memiliki jarak kehamilan yang tidak berisiko tinggi. Status gizi ibu hamil sebagaian besar dalam Kategori Kekurangan Energi Kronik (KEK) dan berat bayi yg dilahirkan dalam kategori BBLR. Sehingga diperoleh simpulan bahwa ada hubungan antara antara status gizi ibu hamil dengan berat badan bayi lahir. Sehingga sangat direkomendasikan bagi ibu hamil untuk memenuhi kebutuhan gizi yang optimal untuk mencegah kelahiran BBLR.

\section{Daftar Pustaka}

Anggrenisa, Rika. 2018. "Faktor - Faktor Yang Berhubungan Dengan Dan Klinik Pratama Jannah Tembung Tahun 2018."

Ani, Feris Ardi, Umaroh, and Triana Sri Hardjanti. 2020. Faktor-Faktor Yang Berhubungan Dengan Berat Badan Lahir Rendah (BBLR) Di Wilayah Kerja UPTD Puskesmas Toroh 1 Kabupaten Grobogan.

Chen, Yi, Guanghui Li, Yan Ruan, Liying Zou, Xin Wang, and Weiyuan Zhang. 2013. "An Epidemiological Survey on Low Birth Weight Infants in China and Analysis of Outcomes of Full-Term Low Birth Weight Infants." BMC Pregnancy and Childbirth 13(1):1-9.

Choudhary, A. K., Asha Choudhary, S. C. Tiwari, and R. Dwivedi. 2013. "Factors Associated with Low Birth Weight among Newborns in an Urban Slum Community in Bhopal." Indian Journal of Public Health 57(1):20.

Jumhati, Siti, and Dian Novianti. 2018. "Analisis Faktor-Faktor Yang Berhubungan Dengan Kejadian BBLR Di Rumah Sakit Permata Cibubur-Bekasi." Jurnal IImu Kesehatan Masyarakat 7(02):113-19.

KEMENKES RI. 2015. Pedoman Pelayanan Antenatal Terpadu (Ke-2). Jakarta: Dirjen Bina Gizi dan KIA Kemenkes RI.

KEMENKES RI. 2018. Petunjuk Teknis Pemberian Makanan Tambahan lbu Hamil (2nd Ed.). Jakarta: KEMENKES RI.

Kurniawan, Bambang, and Tessa Sjahriani. 2014. Hubungan Jarak Kehamilan Dengan Kejadian Bayi Berat Lahir Rendah Di Puskesmas Kecamatan Pademangan Jakarta Utara.

Kusuma, Reni Merta, Yuli Astuti, and Arum Margi Kusumawardhani. 2019. "Relationship of the Arm Circle of the Pregnant Mother with Weight of a New Born Baby Agency." Jurnal Medika Respati 14(2):117-25. 
Mayanda, Vinta. 2017. "Hubungan Status Gizi lbu Hamil Dengan Berat Badan Lahir Rendah (BBLR) RSIA Mutia Sari Keamatan Mandau." Menara IImu $\mathrm{XI}(76): 230-38$.

Momeni, Mohsen, Mina Danaei, Akram Jabbari Nejad Kermani, Marzieh Bakhshandeh, Shohreh Foroodnia, Zahra Mahmoudabadi, Raheleh Amirzadeh, and Hossein Safizadeh. 2017. "Prevalence and Risk Factors of Low Birth Weight in the Southeast of Iran." International Journal of Preventive Medicine 8.

Nasution, Suci Maisyarah. 2018. "Pengaruh Usia Kehamilan, Jarak Kehamilan, Komplikasi Kehamilan, Antenatal Care Terhadap Kejadian Bayi Berat Lahir Rendah (BBLR) Di RSUD Dr. Pirngadi Kota Medan Tahun 2017."

Puskesmas Tunjungan. 2019. Laporan Data Gizi Puskesmas Tunjungan Kabupaten Blora.

Puskesmas Tunjungan. 2020. Capaian UKM Puskesmas Tunjungan Tahun 2020. Blora: UPTD Puskesmas Tunjungan.

Puspitaningrum. 2018. "Hubungan Status Gizi Ibu Hamil Dengan Kejadian BBLR Di RSIA ANNISA Kota Jambi Tahun 2018." 7(2):77-95.

Sujianti. 2018. "Hubungan Usia Ibu Dengan Kejadian Bayi Berat Lahir Rendah (BBLR) Di RSUD Cilacap." Kesehatan Al-Irsyad XI(1):62-67.

Susanti, D. .. 2018. "Faktor-Faktor Yang Berhubungan Dengan Kejadian Bayi Lahir Rendah Di RSUD Wonosari Kabupaten Gunung Kidul Tahun 2016 (Skripsi). Politeknik Kesehatan Yogyakarta." 7-23.
Wibowo, Noroyono, Irma Irwinda, Edwina Frisdiantiny, Made Kornea Karkata, Johanes C. Mose, Maisuri T. Chalid, Rukmono Siswishanto, Bangun Trapsia Purwaka, and CL Tobing. 2016. Diagnosis Dan Tatalaksana Preeklamsia. Jakarta: POGI.

Windari, Fitri. 2015. "Hubungan Tingkat Pendidikan Dan Pekerjaan Ibu Dengan Kejadian Bayi Berat Lahir Rendah Di RSU PKU Muhammadiyah Bantul."

Yuliani, Diki Retno, Suharyo Hadisaputro, and Sri Achadi Nugraheni. 2019. "Distribution of Preeclampsia Risk Factors in Pregnant Woman with Mild Preeclampsia in Banyumas District." JURNAL KEBIDANAN 9(2):135-41.

Yuliani, Diki Retno, Elfirayani Saragih, Anjar Astuti, Wahyuni Wahyuni, Murti Ani, Yanik Muyassaroh, Evita Aurilia Nardina, Ratih Kumala Dewi, Sulfianti Sulfianti, and Ismawati Ismawati. 2021. Asuhan Kehamilan. Yayasan Kita Menulis. 